\title{
Peningkatan Pengetahuan tentang Pencegahan Infeksi dan Penyebaran Penularan COVID-19 di Panti Asuhan/LKSA Darul Tazkiyah Kota Palangka Raya
}

\section{Increasing Knowledge about Prevention of Infection and Spread of COVID-19 Transmission in the Darul Tazkiyah Orphanage/LKSA, Palangka Raya City}

\author{
Dwi Purbayanti ${ }^{*}$ \\ Rinny Ardina ${ }^{1}$ \\ Halida Suryadini ${ }^{2}$ \\ ${ }^{1}$ Department of Medical Laboratory \\ Technology, Universitas \\ Muhammadiyah Palangkaraya, \\ Palangka Raya, Central Kalimantan, \\ Indonesia \\ 2Department of Pharmacy, Universitas \\ Muhammadiyah Palangkaraya, \\ Palangka Raya, Central Kalimantan, \\ Indonesia
}

email: dwipurbayanti@gmail.com

\section{Kata Kunci}

Covid-19

Panti asuhan

Pengetahuan

Keywords:

Covid-19

Orphanage

Knowledge

Received: December 2020

Accepted: February 2021

Published: April 2021

\begin{abstract}
Abstrak
Infeksi COVID-19 tidak memandang usia baik anak-anak, orang dewasa, maupun lansia dapat menjadi korban keganasan virus ini. Anak-anak dan lansia merupakan kelompok yang paling rentan terinfeksi. Panti asuhan yang didalamnya terdapat banyak anak-anak merupakan salah satu tempat yang memiliki risiko tinggi terhadap penularan virus SARS-CoV2. Kegiatan sosialisasi untuk memberikan edukasi tentang pencegahan infeksi dan penyebaran penularan COVID-19 di panti asuhan Darul Tazkiyah kota Palangka Raya menjadi target kegiatan pengabdian. Metode pelaksanaan yang dilakukan antara lain pemberian pre test, edukasi tentang COVID-19, post test, dan penyerahan kalender berisi informasi tentang pencegahan COVID-19, poster, hand sanitizer ekstrak daun sirih, serta spanduk kawasan wajib melaksanakan protokol kesehatan. Sebanyak 46 anak panti asuhan yang menjadi responden, didapatkan hasil uji paired sample t-test dengan p-value $<0,05$ yaitu 0,000 $<0,05$ sehingga dapat disimpulkan ada perbedaan hasil pre test dengan post test yang artinya ada peningkatan pengetahuan dari anak-anak tentang pencegahan infeksi dan penyebaran penularan COVID-19 di Panti Asuhan/LKSA Darul Tazkiyah Kota Palangka Raya setelah diberikan edukasi. Berdasarkan hasil kegiatan pengabdian yang dilakukan, nampak bahwa pemberian edukasi dapat meningkatkan pengetahuan anak-anak tentang upaya pencegahan penularan COVID19, sehingga diharapkan dengan meningkatnya pengetahuan ini dapat meminimalisir penularan COVID-19 dan membantu program pemerintah untuk mengurangi kasus positif COVID-19 di Palangka Raya secara khususnya.
\end{abstract}

\begin{abstract}
COVID-19 infection regardless of age. It can infect children, adults, and older adults. Children and older adults are high-risk groups of infection. An orphanage where many children live in one place with a high risk of transmission of the SARS-CoV-2 virus. Education about prevention of infection and the spread of COVID-19 transmission at Darul Tazkiyah orphanage Palangka Raya was needed. The implementation methods included a pre-test, education about COVID-19, post-test, and submission of calendars containing information on prevention of COVID-19, posters, betel leaf extract hand sanitizers and health protocols banners. A total of 46 orphanage children became respondents. The paired sample t-test showed that $p$-value $(0.000)<0.05$. It meant there was a difference between pre-test and post-test results, which meant there was an increasing children's knowledge about prevention of infection and the spread of COVID-19 transmission at Darul Tazkiyah Orphanage, Palangka Raya. Based on the results of the service activities carried out, it showed that providing education can increase children's knowledge about how efforts to prevent transmission of COVID-19, so it is hoped that this increased knowledge can minimize transmission of COVID-19 and help government programs to reduce positive cases of COVID-19 in Palangka Raya in particular.
\end{abstract}




\section{PENDAHULUAN}

Coronavirus ditularkan melalui mikrodroplet yang sangat kecil saat seseorang berbicara atau batuk, dapat bertahan lama di udara, dan menimbulkan risiko paparan kepada orang lain dengan jarak 1-2 meter dari orang yang terinfeksi (Morawska \& Milton, 2020). Infeksi coronavirus ini menimbulkan gejala seperti pneumonia, demam, kesulitan bernafas, dan infeksi pernafasan. Oleh World Health Organization (WHO) penyakit yang disebabkan oleh novel coronavirus pada tahun 2019 ini diumumkan dengan nama coronavirus disease (COVID19) dan nama referensi untuk virus ini yaitu severe acute respiratory syndrome coronavirus 2 (SARS-CoV-2) (Adhikari et al., 2020).

Pandemi virus corona 2019 (Covid-19) adalah masalah yang sedang dihadapi di lebih dari 200 negara di dunia. Indonesia juga terkena dampak buruk dari COVID-19 dimana tingkat kematiannya mencapai 8,9\% pada akhir Maret 2020 (World Health Organization, 2020). Adapun data terakhir di Kalimantan Tengah menunjukkan terdapat 7409 kasus positif COVID-19 dengan angka kematian 3\% dan ini sudah jauh menurun dibandingkan pada bulan Mei 2020 lalu (4,8\%) (Media Center Satuan Tugas COVID-19 Kalimantan Tengah, 2020). Angka kasus positif ini terus naik meskipun juga dibarengi dengan peningkatan angka kesembuhan yang cukup signifikan jika dilihat dari data per harinya. Hingga saat ini infeksi SARS-CoV-2 belum ditemukan obat dan vaksinnya (Kementerian Kesehatan Republik Indonesia, 2020).

Dalam rangka upaya pencegahan penularan COVID-19, pemerintah Indonesia telah menekankan kepada seluruh masyarakat untuk membudayakan perilaku hidup bersih dan sehat melalui berbagai cara diantaranya cuci tangan menggunakan sabun dengan air mengalir atau hand sanitizer secara rutin, membatasi menyentuh wajah sebelum mencuci tangan, menerapkan etika batuk, membatasi berjabat tangan, meningkatkan daya tahan tubuh dengan konsumsi gizi seimbang, minum air yang cukup dan aktifitas fisik minimal 30 menit/hari, menjaga jarak terutama pada orang yang sedang demam/batuk/bersin (Kementerian Kesehatan Republik Indonesia, 2020).

Infeksi COVID-19 tidak memandang usia. Anak-anak, orang dewasa, maupun lansia dapat menjadi korban keganasan virus ini. Anak-anak dan lansia merupakan kelompok yang paling rentan terinfeksi sebab sistem imun tubuh kedua golongan ini termasuk cukup rendah. Oleh sebab itu, penting bagi kita untuk menjaga anakanak serta lansia secara ekstra agar terhindar dari infeksi virus COVID-19. Social distancing merupakan salah satu langkah krusial untuk memutus mata rantai penularan COVID-19. Tempat-tempat yang sangat perlu diterapkan social distancing adalah tempat-tempat yang padat penduduknya, salah satunya ialah panti asuhan yang didalamnya banyak anak-anak yang rentan terhadap infeksi virus ini. Sehingga perlu dilakukan sosialisasi kepada mereka untuk menerapkan pola hidup bersih dan sehat.

Salah satu tempat yang harus menjadi perhatian saat wabah COVID-19 ini ialah panti asuhan. Dimana banyak anak-anak yang harus dijaga dan dirawat selama wabah COVID-19 ini terjadi. Panti asuhan atau Lembaga Kesejahteraan Sosial Anak (LKSA) merupakan salah satu lembaga atau wadah yang dibentuk oleh pemerintah, pemerintah daerah atau masyarakat setempat yang bertanggungjawab dalam pengasuhan anak. Yayasan panti asuhan/LKSA Darul Tazkiyah merupakan salah satu LKSA di kota Palangka Raya beralamat di Jl. Danau Rangas Km. 6,5 Tjilik Riwut. LKSA Darul Tazkiyah yang mengasuh cukup banyak anak yaitu terdapat 76 anak dari anak usia pra sekolah hingga usia remaja (17-18 tahun). Fasilitas yang ada di LKSA antara lain kantor LKSA, asrama laki-laki, asrama 
perempuan, fasilitas MCK (mandi, cuci, kakus), dan mesjid.

Ditinjau dari fasilitas LKSA Darul Tazkiyah, masih besar potensi akan terjadinya penularan berbagai penyakit, terutama COVID-19 pada anak-anak dan juga pengasuh jika tidak rutin menerapkan pola hidup bersih dan sehat. Perlunya peningkatan kesadaran masyarakat untuk berperilaku hidup bersih dan sehat, seperti kesadaran mencuci tangan menggunakan sabun menyebabkan harus gencarnya sosialisasi untuk penerapan perilaku ini. Berbagai media untuk mensosialisasikan cara mencuci tangan yang benar telah banyak digunakan diantaranya media televisi, akun sosial media, koran, bahkan ada pula melalui mobil kampanye. Tindakan sosialisasi ini masih terus dilakukan oleh berbagai pihak sebab berdasarkan observasi terutama di kota Palangka Raya masih banyak ditemukan masyarakat yang tidak peduli dengan cara mencuci tangan yang benar.

Meskipun saat ini sudah banyak tempat yang menyediakan sarana mencuci tangan, namun masih ada beberapa tempat lain dimana masyarakat tidak dapat menemukan air mengalir ataupun tidak tersedianya sabun, sehingga alternatif lain yang dilakukan masyarakat adalah dengan menggunakan hand sanitizer yang dinilai lebih praktis. Perilaku mencuci tangan menggunakan sabun atau hand sanitizer yang meningkat, menyebabkan tingginya angka pembelian sabun dan hand sanitizer. Bahkan sempat dalam beberapa minggu di seluruh kota di Indonesia terjadi kelangkaan hand sanitizer akibat panic buying. Kelangkaan hand sanitizer di pasaran serta munculnya ide membuat hand sanitizer mandiri menyebabkan terjadinya kelangkaan bahan lain yaitu alkohol $96 \%$ atau $70 \%$ sebagai bahan dasar pembuatan hand sanitizer.

Efek domino yang disebabkan oleh kelangkaan hand sanitizer dan tingginya harga hand sanitizer serta alkohol, akhirnya memicu ide lain yaitu ide untuk membuat hand sanitizer dari bahan-bahan alami yang mudah ditemukan dan dibuat, murah, dan juga dapat ditanam di pekarangan. Beberapa jenis tanaman yang dapat dijadikan bahan hand sanitizer ialah kulit nanas, daun seledri, daun jambu mete, kulit jeruk, kulit pisang, buah belimbing wuluh, daun sirsak, daun sirih hijau, aloe vera, daun sirih merah, dan masih banyak tanaman lainnya (Hamzah, 2020).

Salah satu tanaman yang dapat digunakan sebagai antiseptik ialah daun sirih merah dan di Kota Palangka Raya sirih merah sudah cukup terkenal digunakan untuk pengobatan tradisional. Daun sirih merah atau Piper crocatum telah lama diketahui sebagai antiseptik tradisional yang sering digunakan oleh masyarakat Indonesia (Prabowo et al., 2018). Diketahui bahwa daun sirih merah mengandung senyawa-senyawa antibakteri seperti flavonoid, alkaloid senyawa polifenol, tanin dan minyak atsiri (Puspita et al., 2018). Flavonoid, alkaloid, tanin dan minyak atsiri pada daun sirih merah berfungsi sebagai zat aktif antibakteri diantaranya Staphylococcus aureus, Escherichia coli, dan Candida albicans (Candrasari et al., 2012). Selain itu secara empiris zat aktif tersebut juga memiliki efek mencegah ejakulasi dini, antikejang, membasmi kuman, penghilang rasa nyeri dan menghilangkan bengkak, mengatasi radang paru, radang tenggorokan, gusi bengkak, radang payudara, hidung mimisan, kencing manis, ambeien, jantung koroner, darah tinggi, asam urat, dan batuk berdarah (Hermiati et al., 2013). Baru-baru ini daun sirih merah juga dijadikan bahan pembuatan hand sanitizer ditengah mahalnya pembelian hand sanitizer buatan pabrik.

Pembuatan hand sanitizer dengan bahan daun sirih merah pun cukup mudah untuk dapat diterapkan oleh masyarakat di rumah. Daun sirih merah segar dicuci dan dibersihkan, dipotong kecil-kecil, lalu sebanyak 50 gram daun sirih merah yang telah dipotong dimasukkan ke dalam panci berisi air sebanyak $100 \mathrm{ml}$. Daun 
dipanaskan selama 15 menit pada air mendidih sambil diaduk. Kemudian rebusan disaring dan diperas selagi panas dengan kain bersih, lalu tambahkan air panas hingga total volume yang diperoleh adalah $100 \mathrm{ml}$, maka jadilah ekstrak daun sirih merah. Hasil penelitian Prabowo et al. (2018) menunjukkan bahwa ekstrak daun sirih merah baik dengan stabilitas penyimpanan pada suhu 18-27oC dengan $\mathrm{pH} 5,5$ dan warna bening kekuningan. Konsentrasi sediaan daun sirih merah efektif pada konsentrasi 25\% terhadap mikroba tangan dimana ini setara dengan hand sanitizer alkohol.

Cukup mudahnya pembuatan hand sanitizer dengan bahan alami dan perlunya sosialisasi pencegahan penularan Covid-19 membuat tim pengabdian merasa perlu untuk melakukan kegiatan ini di Panti Asuhan/LKSA Darul Tazkiyah dengan berbagai cara yaitu pembagian kalender dan poster, demonstrasi pembuatan hand sanitizer, dan penyerahan bibit tanaman sirih merah.

\section{METODOLOGI}

\section{Alat dan Bahan}

Lembar angket, laptop, LCD, kalender, poster, hand sanitizer ekstrak daun sirih, dan bibit daun sirih merah dan daun sirih hijau.

\section{Metode Pelaksanaan}

1. Observasi dan Wawancara

Observasi dan wawancara kepada Ketua Panti Asuhan Darul Tazkiyah dilakukan dengan maksud untuk menggali informasi lebih dalam tentang permasalahan mitra yang selama ini terjadi terutama tentang kesehatan anak-anak panti, upaya pencegahan yang telah dilakukan selama wabah COVID-19 dan melihat secara langsung kondisi sarana prasarana di panti asuhan yang mendukung kemungkinan risiko penularan COVID-19.

\section{Perijinan}

Tahapan perijinan dilakukan dengan pengajuan surat ijin ke panti asuhan Darul Tazkiyah untuk memberitahukan maksud dan tujuan kegiatan, rencana pelaksanaan kegiatan yang akan dilakukan, dan manfaat dari kegiatan bagi anak-anak asuh dan juga pengasuh di panti asuhan Darul Tazkiyah.

\section{Persiapan}

Tahapan persiapan dilakukan setelah disepakatinya jadwal pelaksanaan kegiatan dengan Mitra. Tim akan berkoordinasi kembali dengan Mitra untuk merencanakan teknis pelaksanaan, siapa saja pihak panti asuhan yang akan terlibat, dan penjelasan tugas masing-masing anggota. Selanjutnya melakukan persiapan kegiatan seperti menyediakan kalender dan poster tentang cara-cara pencegahan penularan dan penyebaran COVID-19, angket yang berisi pertanyaan untuk menilai pengetahuan anak-anak tentang cara-cara penularan dan penyebaran COVID-19 serta penyerahan daun sirih merah dan daun sirih hijau untuk ditanam di pekarangan panti asuhan Darul Tazkiyah.

4. Pelaksanaan

Kegiatan sosialisasi pencegahan infeksi dan penyebaran penularan COVID-19 di panti asuhan ini disertai dengan pembagian kalender dan poster tentang cara pencegahan infeksi dan penyebaran penularan COVID-19, demonstrasi singkat tentang cara pembuatan hand sanitizer menggunakan daun sirih, dan pembagian bibit daun sirih sebagai salah satu tanaman herbal yang dapat digunakan untuk membuat hand sanitizer. Tahap pertama yaitu anakanak dan pengasuh panti akan diberikan arahan tentang kegiatan apa saja yang akan dilakukan selama tim berada di panti asuhan. Setelah diberikan pengarahan, tim akan membagikan angket yang berisi pertanyaan tentang sejauh mana pengetahuan 
anak-anak tentang cara pencegahan infeksi dan penyebaran penularan COVID-19. Tahap kedua, setelah angket terkumpul tim akan memberikan penjelasan tentang pengertian dari Covid-19, cara penularan COVID-19, 6 langkah mencuci tangan yang benar menurut WHO, etika batuk, manfaat dan cara penggunaan hand sanitizer, serta cara pengolahan hand sanitizer sederhana mengguanakan daun sirih. Tahap ketiga, pembagian angket kembali untuk menilai ada/tidaknya peningkatan pengetahuan dari anak-anak panti asuhan Darul Tazkiyah setelah dilakukan sosialisasi. Tahap keempat, demonstrasi singkat tentang cara pembuatan hand sanitizer menggunakan daun sirih, dan pembagian bibit daun sirih.

\section{Evaluasi dan Pelaporan}

Pada tahap ini tim akan melakukan evaluasi dan pelaporan satu minggu setelahnya kepada pengasuh panti asuhan Darul Tazkiyah tentang tingkat pengetahuan anak-anak dan pengasuh panti terhadap pencegahan infeksi dan penyebaran penularan COVID-19.

\section{HASIL DAN PEMBAHASAN}

Kegiatan pengabdian yang dilaksanakan pada tanggal 28 Oktober 2020 di Panti Asuhan Darul Tazkiyah kota Palangka Raya melibatkan mahasiswa, laboran dan dosen. Jumlah peserta (anak asuh) yang berpartisipasi dalam kegiatan pengabdian kepada masyarakat ini sebanyak 46 orang dan didampingi 5 orang pengelola panti. Kegiatan pertama yang dilakukan ialah tim memberikan arahan kepada anak asuh dan pengelola panti tentang rangkaian kegiatan yang akan dilakukan (Gambar 1). Kemudian tim membagikan angket yang berisi pertanyaan tentang sejauh mana pengetahuan anak-anak tentang cara pencegahan infeksi dan penyebaran penularan COVID-19 (Gambar 2).

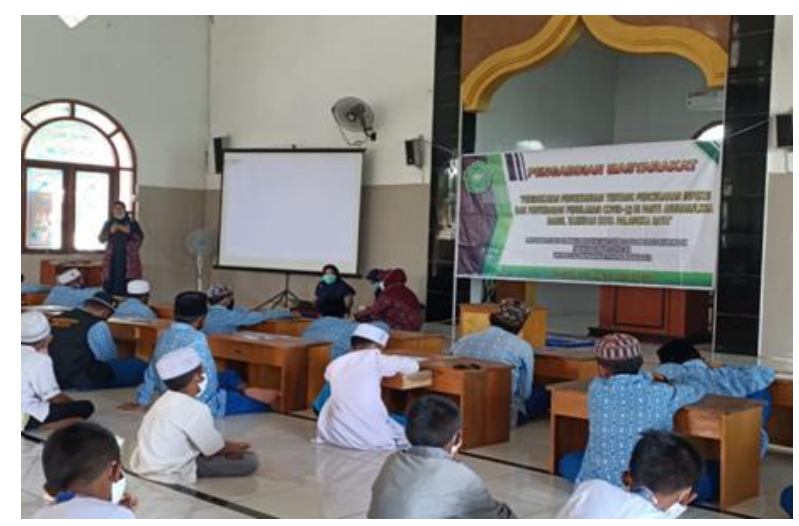

Gambar 1. Pengarahan kegiatan pengabdian kepada masyarakat

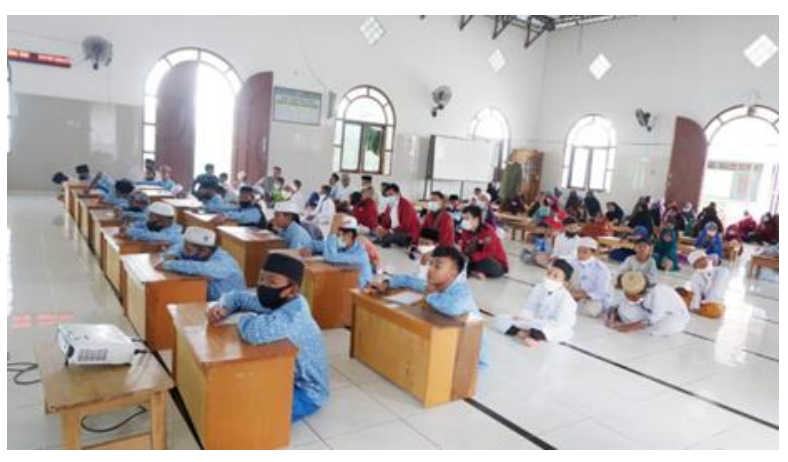

Gambar 2. Pre-test

Kegiatan kedua, setelah angket terkumpul tim selanjutnya memberikan edukasi tentang pengertian COVID-19, cara penularan COVID-19, 6 langkah mencuci tangan yang benar menurut $\mathrm{WHO}$, etika batuk, manfaat dan cara penggunaan hand sanitizer, serta cara pengolahan hand sanitizer sederhana mengguanakan daun sirih (Gambar 3).

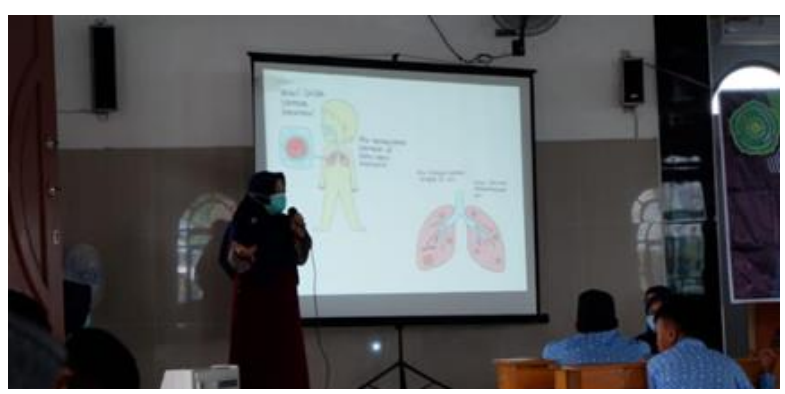

Gambar 3. Edukasi tentang COVID-19

Kegiatan ketiga, pembagian angket yang sama sebagai bentuk post test untuk menilai ada/tidaknya peningkatan pengetahuan dari anak-anak panti asuhan setelah pemberian edukasi (Gambar 4). 


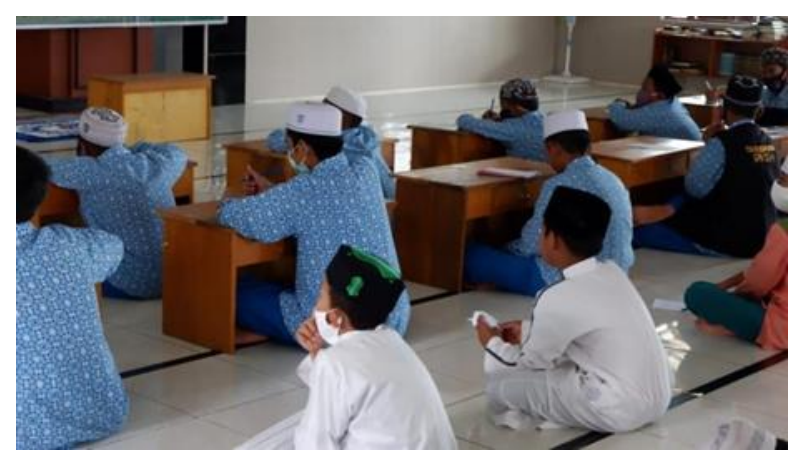

Gambar 4. Post-test

Kegiatan keempat, pembagian kalender pencegahan COVID-19, hand sanitizer, poster, dan spanduk kawasan wajib mematuhi protokol kesehatan kepada pengelola panti asuhan Darul Tazkiyah (Gambar 5).

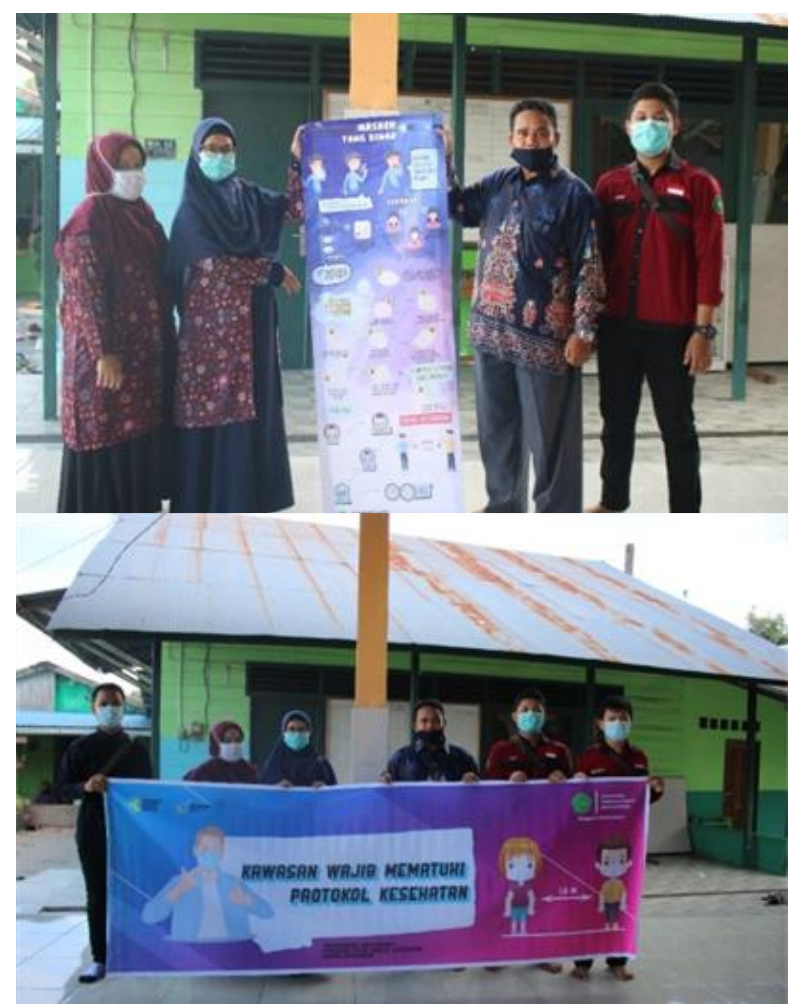

Gambar 5. Pembagian kalender, hand sanitizer, poster (atas), dan spanduk kawasan wajib mematuhi protokol kesehatan (bawah) kepada pengelola panti asuhan Darul Tazkiyah

Pada akhir kegiatan tim pengabdian, menyerahkan secara langsung bibit sirih merah dan sirih hijau kepada pengelola panti asuhan Darul Tazkiyah agar dapat ditanam dan selanjutnya dipanen untuk diaplikasikan dalam pembuatan hand sanitizer maupun manfaat herbal lainnya dari daun sirih tersebut (Gambar 6).

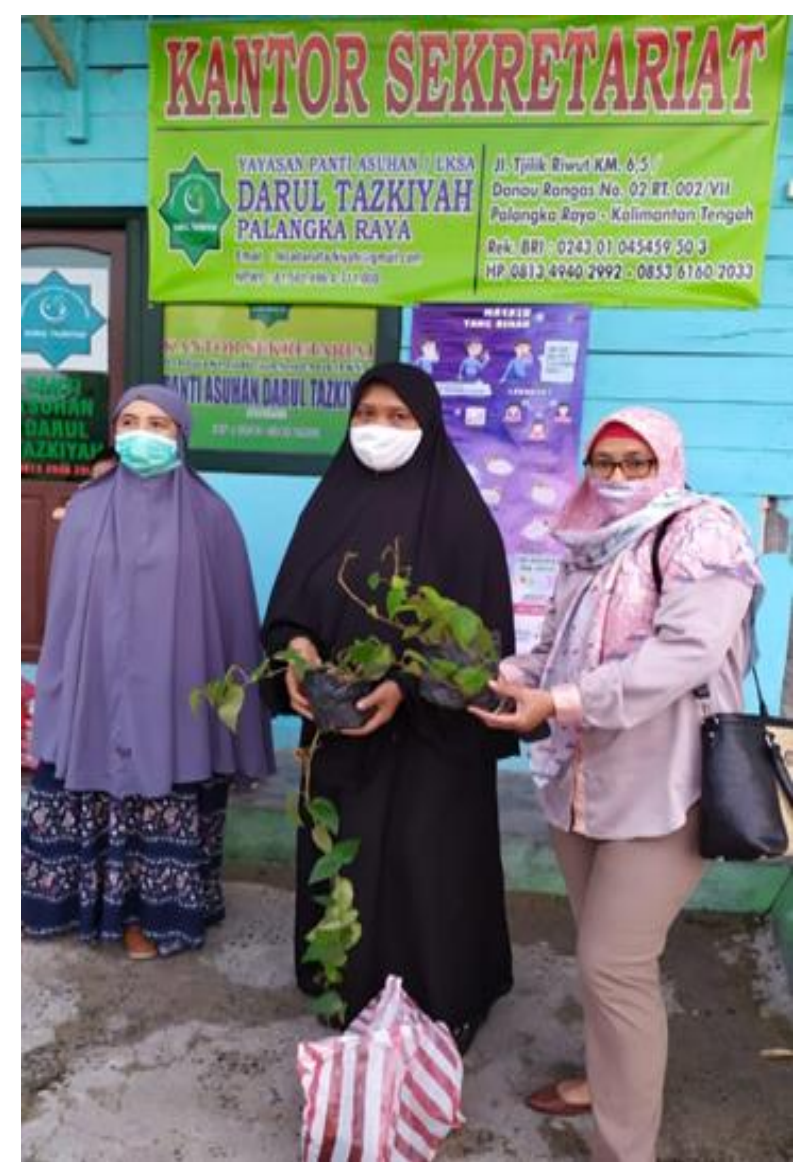

Gambar 6. Penyerahan bibit sirih merah dan sirih hijau

Setelah rangkaian kegiatan pengabdian selesai, tim melakukan evaluasi terhadap kegiatan dan melakukan analisis data terhadap hasil pre-test dan post-test anakanak panti asuhan. Hasil pre-test dan post-test selanjutnya dianalisis secara statistik dengan menggunakan uji paired sample $t$-test dan didapatkan nilai sig. 0,000 >0,05 sehingga Ho ditolak dan Ha diterima. Dapat disimpulkan bahwa ada perbedaan antara hasil pre-test dengan post-test yang artinya ada peningkatan pengetahuan dari anak-anak panti asuhan tentang pencegahan infeksi dan penyebaran penularan COVID19 di Panti Asuhan/LKSA Darul Tazkiyah Kota Palangka Raya setelah diberikan edukasi. Hasil ini serupa dengan hasil Zukmadini et al. (2020) dimana persentase pengetahuan peserta sebelum diberikan edukasi yaitu sebesar $74,48 \%$ yang kemudian meningkat menjadi $86,49 \%$ setelah diberikan edukasi. Selain itu, hasil kegiatan Erlin et al. (2020) menemukan peningkatan 
pengetahuan tentang pencegahan penularan COVID-19 dari 100\% berpengetahuan rendah menjadi $75 \%$ berpengetahuan tinggi. Wardhani et al. (2020) mendapatkan hasil adanya peningkatan pengetahuan tentang menjaga kebersihan diri melalui kebiasaan mencuci tangan dalam kehidupan sehari-hari untuk mencegah penularan COVID-19.

Kegiatan pengabdian yang dilaksanakan, diharapkan juga dapat meningkatkan kesadaran kepada anak-anak maupun pengelola panti asuhan Darul Tazkiyah untuk membudayakan pola hidup bersih tidak hanya selama pandemi COVID-19 tetapi dapat menjadi kebiasaan dikemudian hari. Mengingat belum adanya obat maupun vaksin yang dapat diberikan kepada seluruh masyarakat, pencegahan terbaik untuk menghindari terinfeksi virus SARS-CoV-2 ialah melalui Infection preventive and control (IPC) meliputi: penggunaan masker wajah; menutupi batuk dan bersin dengan tisu yang kemudian dibuang dengan aman; mencuci tangan secara teratur dengan sabun atau hand sanitizer (jika sabun dan air tidak tersedia); menghindari kontak dengan orang yang terinfeksi dan menjaga jarak; dan menahan diri untuk menyentuh mata, hidung, dan mulut (Centers for Disease Control and Prevention, 2020).

\section{KESIMPULAN}

Upaya pencegahan penularan COVID-19 tidak hanya menjadi tanggungjawab salah satu bidang saja tetapi hal ini menjadi tanggung jawab bersama berbagai bidang/sektor. Berdasarkan hasil kegiatan pengabdian ini dan berbagai hasil temuan serupa, nampak bahwa pemberian edukasi dapat meningkatkan pengetahuan anak-anak tentang upaya pencegahan penularan COVID-19, sehingga diharapkan dengan meningkatnya pengetahuan ini dapat meminimalisir penularan COVID-19 dan membantu program pemerintah.

\section{UCAPAN TERIMA KASIH}

Terima kasih kepada Universitas Muhammadiyah Palangkaraya, khususnya Lembaga Penelitian dan Pengabdian kepada Masyarakat (LP2M) Universitas Muhammadiyah Palangkaraya atas bantuan dana Program Kemitraan Masyarakat Stimulus tahun 2020 sehingga kegiatan pengabdian ini dapat dilaksanakan.

\section{REFERENSI}

Adhikari, S.P., Meng, S., Wu, Y.J., Mao, Y.P., Ye, R.X., Wang, Q.Z., Sun, C., Sylvia, S., Rozelle, S., Raat, H., Zhou H. 2020. Epidemiology, causes, clinical manifestation and diagnosis, prevention and control of coronavirus disease (COVID-19) during the early outbreak period: a scoping review. Infectious Diseases of Poverty. 9:29. https://dx.doi.org/10.1186/s40249-02000646-x

Candrasari, A., Romas, M.A., Astuti, O.R. 2012. Uji Daya Antimikroba Ekstrak Etanol DaunSirih Merah (Piper Crocatum Ruiz \& Pav.) terhadap Pertumbuhan Staphylococcus aureus ATCC 6538, Eschericia coli ATCC 11229 dan Candida albicans ATCC 10231 secara In Vitro. Biomedika. $\quad 4(1): 9-16$. https://doi.org/10.23917/biomedika.v4i1.25 8

Centers for Disease Control and Prevention. 2020. Novel coronavirus, Wuhan, China. https://www.cdc.gov/coronavirus/2019ncov/index.html

Erlin, F., Putra, I.D., Hendra, D. 2020. Peningkatan Pengetahuan Siswa Dalam Pencegahan Penularan COVID-19. JMM (Jurnal Masyarakat Mandiri). $4(4): 7-9$. https://doi.org/10.31764/jmm.v4i4.2652

Hamzah, A.T. 2020. Herbal Potensial Sebagai Hand Sanitizer di Indonesia: Literatur Review. Pasapua Health Journal. 2(1):31-39.

Hermiati, Rusli, Manalu, N.Y., Sinaga, M.S. 2013. Ekstrak Daun Sirih Hijau Dan Merah Sebagai Antioksidan Pada Minyak Kelapa. Jurnal Teknik Kimia USU. 2(1):37-43. https://doi.org/10.32734/jtk.v2i1.1425 
Kementerian Kesehatan Republik Indonesia. 2020. Himbauan Tentang Upaya Pencegahan Penularan Covid-19 di Tempat Kerja. Jakarta: Kementerian Kesehatan Republik Indonesia

Media Center Satuan Tugas COVID-19 Kalimantan Tengah. 2020. Peta Sebaran Kasus COVID-19. https://corona.kalteng.go.id/

Morawska, L., Milton, D.K. 2020. It Is Time to Address Airborne Transmission of Coronavirus Disease 2019 (COVID-19). Clinical Infectious Diseases. 71(9):2311-2313. https:/ /doi.org/10.1093/cid/ciaa939

Prabowo, W.C., Widayat, W., Defriana, S. 2018. Formulasi Infusan Daun Sirih Merah (Piper crocatum) Sebagai Gel Antiseptik Tangan. Jurnal Sains dan Kesehatan. 1(10):525-530. https://doi.org/10.25026/jsk.v1i10.59

Puspita, P.J., Safithri, M., Sugiharti, N.P. 2018. Antibacterial Activities of Sirih Merah (Piper crocatum) Leaf Extracts. Current Biochemistry. 5(3):1-10. https://doi.org/10.29244/cb.5.3.110

Wardhani, D.K., Susilorini, M.R., Angghita, L.J., Ismail, A. 2020. Edukasi Pencegahan Penularan COVID-19 Pada Anak Usia Dini Melalui Media Pembelajaran Audio Visual. Jurnal Abdidas. 1(3):131-136. https://doi.org/10.31004/abdidas.v1i3.33

World Health Organization. 2020. Coronavirus disease (COVID-19) situation dashboard. https:/ / covid19.who.int/

Zukmadini, A.Y., Karyadi, B., Kasrina, K. 2020. Edukasi Perilaku Hidup Bersih dan Sehat (PHBS) dalam Pencegahan COVID-19 Kepada AnakAnak di Panti Asuhan. Jurnal Pengabdian Magister Pendidikan IPA. 3(1):68-76. https://doi.org/10.29303/jpmpi.v3i1.440 